\title{
ANALISIS EKONOMI POTENSIAL SEBAGAI DASAR DALAM PERENCANAAN DAN PERTUMBUHAN PEMBANGUNAN KOTA BIMA PROVINSI NUSA TENGGARA BARAT
}

\author{
Mukhlis \\ mukhlisbima@gmail.com
}

\begin{abstract}
ABSTRAK
Penelitian dengan judul Analisis Ekonomi Potensial Sebagai Dasar Dalam Perencanaan dan Pertumbuhan Pembangunan Kota Bima Provinsi NTB. Tujuan penelitian ini untuk: (1) Mengidentifikasi dan menganalisis sektor/subsektor ekonomi potensial di Kota Bima, berdasarkan kriteria keunggulan komparatif, keunggulan kompetitif, dan spesialisasi. (2) Mengetahui pola dan struktur pertumbuhan ekonomi Kota Bima baik secara sektoral maupun secara agregat terhadap Provinsi Nusa Tenggara Barat. Metode analisis yang dipakai dalam penelitian ini adalah metode analisis Location Quatient (LQ). Data yang digunakan adalah data PDRB Kota Bima mulai tahun 2012 sampai dengan tahun 2015. Sumber dataBadan Pusat Statistik (BPS) Kota Bima. Dari hasil analisis data dapat disimpulkan antara lain (a) Sektor jasa-jasa menempati peringkat tertinggi dengan rata-rata sebesar 2,000 dan masih menjadi sektor basis atau sektor tersebut merupakan sektor potensial. (b) Sektor listrik, gas dan air bersih serta sektor pengangkutan dan komunikasi masing-masing rata-rata sebesar 1,952 dan 1,711 tetap menjadi sektor basis. (c) Sementara itu sektor-sektor yg lain masing-masing dengan rata-rata yaitu : sektor perdagangan $(0,985)$, sektor keuangan, persewaan dan jasa perusahaan $(0,832)$, sektor bangunan $(0,768)$, sektor pertanian $(0,663)$, sektor industri pengolahan $(0,574)$ serta sektor pertambangan dan penggalian $(0,004)$ bukan merupakan sektor basis.
\end{abstract}

Kata Kunci : Ekonomi Potensial, Sektor Basis, Location Quetient

\section{PENDAHULUAN}

Pembangunan ekonomi merupakan serangkaian usaha dan kebijakan yang bertujuan untuk meningkatkan taraf hidup masyarakat, memperluas lapangan kerja, memeratakan distribusi pendapatan, meningkatkan hubungan ekonomi regional dan mengusahakan pergeseran kegiatan ekonomi dari sektor primer ke sektor sekunder dan tersier. Dalam kerangka perekonomian daerah, Arsyad (1999) menyatakan bahwa pembangunan ekonomi daerah adalah proses dimana pemerintah daerah dan masyarakat mengelola sumberdaya yang ada dan membentuk suatu pola kemitraan antara pemerintah dengan sektor swasta untuk menciptakan suatu lapangan kerja baru dan merangsang perkembangan kegiatan ekonomi daerah. Dalam kerangka pencapaian tujuan pembangunan ekonomi 


\section{"Jurnal PenKoMi : Kajian Pendidikan dan Ekonomi" STKIP Bima Vol. 2, No. 1 Januari 2019

daerah tersebut dibutuhkan kebijakan pembangunan yang didasarkan pada kekhasan daerah (endogenous development), dengan menggunakan potensi sumberdaya lokal.

Dalam upaya mendorong peningkatan partisipasi dan kreativitas masyarakat dalam pembangunan daerah maka pemerintah mengeluarkan kebijakan otonomi daerah melalui Undang-Undang Nomor 22 Tahun 1999 tentang Pemerintahan Daerah dan Undang-Undang Nomor 25 tahun 1999 tentang Perimbangan Keuangan antara Pusat dan Daerah. Otonomi daerah merupakan perwujudan kewenangan daerah untuk mengatur dan mengurus kepentingan masyarakat setempat menurut prakarsa sendiri berdasarkan aspirasi masyarakat sesuai dengan peraturan perundang-undangan. Undang-Undang Nomor 22 tahun 1999 juga mengatur penyelenggaraan pemerintahan daerah dan pelaksanaan desentralisasi.

Upaya untuk mempercepat pembangunan ekonomi daerah yang efektif dan kuat telah tercantum dalam GBHN 1999-2004, yaitu dengan memberdayakan pelaku dan potensi daerah serta memperhatikan penataan ruang, baik fisik maupun sosial sehingga terjadi pemerataan pertumbuhan ekonomi sejalan dengan pelaksanaan otonomi daerah. Sejalan pula dengan isu lintas bidang yang tercantum dalam Program Pembangunan Nasional (Propenas 2000-2004) bahwa untuk meningkatkan dan mempercepat pembangunan daerah dilakukan dengan konsep pembangunan lintas wilayah. Isu pembangunan lintas wilayah mencakup upaya pengembangan wilayah untuk mendayagunakan potensi dan kemampuan daerah dengan berbagai alat kebijakan yang mendukung perkembangan perekonomian daerah, berkembangnya pemukiman, perkotaan, pedesaan, wilayah cepat tumbuh, perbatasan dan wilayah tertinggal, serta pemberdayaan masyarakat untuk meningkatkan kapasitas masyarakat, meningkatkan hidup dan kehidupannya.

Salah satu implementasi Propenas 2000-2004 mengenai isu pembangunan lintas wilayah adalah upaya pengembangan wilayah. Dalam hal ini pemerintah pusat telah mengakomodir keinginan pemerintah dan masyarakat daerah melalui pemekaran wilayah, baik pada tingkat Provinsi maupun kabupaten/kota. Di lain pihak, setiap daerah memiliki potensi yang berbeda-beda baik dari sisi potensi kandungan sumber daya alam, kondisi geografis maupun potensi khas daerah lainnya. Oleh karena itu penyusunan kebijaksanaan pembangunan daerah, terutama bagi daerah baru, tidak dapat secara serta merta mengadopsi kebijaksanaan nasional, Provinsi maupun daerah induknya atau daerah lain yang dianggap berhasil. Untuk membangun suatu daerah, kebijakan yang diambil harus sesuai dengan masalah, kebutuhan dan potensi daerah yang bersangkutan. Oleh karena itu makalah yang mendalam harus dilakukan untuk memperoleh informasi bagi kepentingan perencanaan pembangunan daerah (Arsyad, 1999). Terkait dengan pentingnya identifikasi kebutuhan dan potensi dalam proses perencanaan pembangunan daerah, maka berbagai pendekatan model perencanaan pembangunan daerah dapat dilakukan untuk menentukan arah dan bentuk kebijakan yang diambil. Salah satu model pendekatan pembangunan daerah adalah pendekatan sektoral. Sebagaimana yang dikemukakan Aziz (1994), pendekatan sektoral dalam perencanaan pembangunan daerah selalu dimulai 


\section{"Jurnal PenKoMi : Kajian Pendidikan dan Ekonomi" STKIP Bima Vol. 2, No. 1 Januari 2019 e-ISSN: 2614-6002}

dengan pertanyaan "sektor ekonomi apa yang perlu dikembangkan". Oleh karena itu identifikasi dan analisis sektor ekonomi potensial menjadi hal penting bagi Kota Bima sebagai daerah otonom yang relatif baru.Kota Bima terbentuk pada tahun 2002 sebagai pemekaran dari Kabupaten Bima. Kota Bima dibentuk berdasarkan Undang-Undang Republik Indonesia Nomor 13 Tahun 2002, secara geografis berada di bagian timur Pulau Sumbawa dengan batas-batas wilayah sebagai berikut:

Sebelah Utara : berbatasan dengan Kecamatan Ambalawi Kabupaten Bima

Sebelah Timur: berbatasan dengan Kecamatan Wawo Kabupaten Bima

Sebelah Selatan: berbatasan dengan Kecamatan Belo Kabupaten Bima

Sebelah Barat : berbatasan dengan Teluk Bima

Kota Bima memiliki luas 222,25 Km2, dan kalau dilihat secara geografis terletak antara posisi 18041 '00" - 1180 48' 00" Bujur Timur dan 80 30' 00" 80 20'00" Lintang Selatan.Secara administratif, Kota Bima terdiri dari 5 (lima) kecamatan yaitu Kecamatan Rasanae Barat, Rasanae Timur, Mpunda, Raba dan Asakota, serta terdiri dari 38 kelurahan. Pembentukan Kota Bima ini dilakukan karena keinginan masyarakat dan dilandasi oleh tujuan sebagai berikut:

1. Memperpendek rentang kendali (span of control) pemerintah, sehingga azas efektifitas dan efisiensi pelaksanaan pembangunan bidang pemerintahan dapat terwujud;

2. Meningkatkan pelayanan terhadap masyarakat;

3. Meningkatkan kemampuan daerah melalui eksploitasi sumber daya alam yang ada pada daerah tersebut secara optimal, guna meningkatkan kesejahteraan masyarakat dan mempercepat pembangunan;

4. Meningkatkan fungsi pengawasan yang efektif terhadap sistem pertahanan dan keamanan wilayah sebagai bagian integral dari sistem pertahanan dan keamanan nasional.

Berikut ini akan ditampilkan data PDRB Atas Dasar Harga Berlaku (ADHB) tahun 2000 menurut lapangan usaha di Kota Bima dari tahun 2004-2007.

Tabel 1.PDRB Kota Bima Atas Dasar Harga Berlaku Tahun 2000 Menurut Lapangan Usaha Tahun 2012-2015 (Juta Rupiah)

\begin{tabular}{|r|l|r|r|r|r|}
\hline No & \multicolumn{1}{|c|}{ Lapangan Usaha } & \multicolumn{1}{c|}{2012} & \multicolumn{1}{c|}{2013} & \multicolumn{1}{c|}{2014} & \multicolumn{1}{c|}{2015} \\
\hline 1 & Pertanian & $80.183,07$ & $79.785,98$ & $79.577,31$ & $82.913,58$ \\
\hline 2 & Pertambangan dan Penggalian & 426,419 & 454,52 & 496,02 & 534,18 \\
\hline 3 & Industri Pengolahan & $11.790,24$ & $12.242,99$ & $12.733,93$ & $13.244,56$ \\
\hline 4 & Listrik, Gas dan Air Bersih & $2.851,33$ & $2.942,50$ & $3.008,78$ & $3.163,42$ \\
\hline 5 & Bangunan & $22.899,94$ & $23.993,21$ & $25.843,08$ & $27.398,84$ \\
\hline & Perdagangan, Hotel dan & & & \\
\hline 6 & Restoran & $59.602,05$ & $63.484,83$ & $67.972,49$ & $72.690,04$ \\
\hline 7 & Pengangkutan dan Komunikasi & $54.847,90$ & $59.071,39$ & $63.990,65$ & $68.699,19$ \\
\hline & Keuangan, Persewaan dan Jasa & $17.203,41$ & $18.174,90$ & $19.492,14$ & $20.874,19$ \\
\hline 8 & Perusahaan & $91.969,85$ & $93.272,09$ & $97.080,48$ & $102.760,41$ \\
\hline 9 & Jasa-Jasa & $\mathbf{3 4 1 . 7 7 4 , 2 0}$ & $\mathbf{3 5 3 . 4 2 2 , 4 1}$ & $\mathbf{3 7 0 . 1 9 4 , 8 8}$ & $\mathbf{3 9 2 . 2 7 8 , 4 1}$ \\
\hline & Jumlah & & & & \\
\hline
\end{tabular}

Sumber :BPS Kota Bima 2015 


\section{"Jurnal PenKoMi : Kajian Pendidikan dan Ekonomi" STKIP Bima Vol. 2, No. 1 Januari 2019}

Jika dilihat secara sektoral pada tabel 1, maka sektor jasa dan sektor pertanian tetap mendominasi kontribusi PDRB atas dasar harga berlaku Kota Bima. Selama tahun 2012-2015 rata-rata pertumbuhan ekonomi sektor pengangkutan dan komunikasi dan sektor perdagangan, hotel dan restoran cukup agresif yaitu sebesar 16,62 persen dan 17,86 persen. Sedangkan untuk sektor listrik, gas dan air bersih di peringkat nomor dua terrendah dan sektor pertambangan dan penggalian merupakan sektor yang terrendah atau paling sedikit menyumbang kontribusi PDRB atas dasar harga berlaku di Kota Bima.

Dengan melihat pembangunan ekonomi Kota Bima melalui deskripsi struktur dan pertumbuhan ekonomi, maka tampak bahwa Kota Bima merupakan wilayah pusat pertumbuhan baru yang berkembang cukup pesat. Namun pembangunan ekonomi suatu wilayah, tidak cukup hanya dilihat dari sisi struktur dan pertumbuhan ekonomi saja. Menurut Thoha dan Soekarni (2000), selain struktur dan pertumbuhan ekonomi, kemampuan (potensi) ekonomi suatu wilayah dapat diukur melalui track record indikator-indikator ekonomi seperti: income per kapita, keunggulan komparatif, keunggulan kompetitif dan lain-lain. Selain itu sebagai wilayah baru, sangat penting untuk mengetahui bagaimana kinerja perekonomian, pola struktur pertumbuhan ekonomi baik secara wilayah (posisi relatif) maupun secara sektoral (antar sektor) dan bagaimana pula tingkat spesialisasi perekonomian di Kota Bima.

Berdasarkan uraian di atas, maka identifikasi dan analisis sektor maupun subsektor ekonomi potensial dalam perencanaan pembangunan Kota Bima, dengan melakukan perbandingan terhadap kondisi perekonomian Provinsi Nusa Tenggara Barat sangat penting untuk dikaji secara lebih terinci, sehingga kegiatan-kegiatan ekonomi potensial Kota Bima dapat lebih dikembangkan. Dengan mengetahui potensi ekonomi yang layak dikembangkan, maka penyusunan perencanaan pembangunan Kota Bima diharapkan lebih terarah sehingga merangsang terciptanya pembangunan yang berkelanjutan (sustainable development).

Sebagai perbandingan dan untuk menghitung sektor ekonomi potensial (basis) dengan menggunakan metode Location Quotient (LQ) maka selanjutnya akan disajikan data PDRB Atas Dasar Harga Berlaku (ADHB) tahun 2000 menurut lapangan usaha Provinsi Nusa Tenggara Barat dari tahun 2012-2015.

Tabel 2. PDRB Provinsi NTB Atas Dasar Harga Berlaku Tahun 2000 Menurut Lapangan Usaha Tahun 2012-2015 (Milyar Rupiah)

\begin{tabular}{|c|l|r|r|r|r|}
\hline No & \multicolumn{1}{|c|}{ LAPANGAN USAHA } & $\mathbf{2 0 1 2}$ & $\mathbf{2 0 1 3}$ & $\mathbf{2 0 1 4}$ & \multicolumn{1}{c|}{$\mathbf{2 0 1 5}$} \\
\hline 1 & Pertanian & $5.172,68$ & $5.815,16$ & $6.505,20$ & $7.181,23$ \\
\hline 2 & Pertambangan dan Penggalian & $7.970,08$ & $9.288,14$ & $10.104,78$ & $12.669,02$ \\
\hline 3 & Industri Pengolahan & 763,78 & 868,58 & 948,80 & $1.083,50$ \\
\hline 4 & Listrik, Gas dan Air Bersih & 84,54 & 99,11 & 112,99 & 130,55 \\
\hline 5 & Bangunan & $1.314,35$ & $1.470,90$ & $1.649,79$ & $1.917,45$ \\
\hline 6 & Perdagangan, Hotel dan Restoran & $2.535,99$ & $2.923,36$ & $3.384,60$ & $3.951,54$ \\
\hline 7 & Pengangkutan dan Komunikasi & $1.457,37$ & $1.994,62$ & $2.236,90$ & $2.456,41$ \\
\hline 8 & $\begin{array}{l}\text { Keuangan, Persewaan dan Jasa } \\
\text { Perusahaan }\end{array}$ & 892,98 & 998,35 & $1.141,13$ & $1.315,74$ \\
\hline
\end{tabular}

78 | Program Studi Pendidikan Ekonomi, Sekolah Tinggi Keguruan dan IImu Pendidikan (STKIP) Bima 
"Jurnal PenKoMi : Kajian Pendidikan dan Ekonomi" STKIP Bima Vol. 2, No. 1 Januari 2019

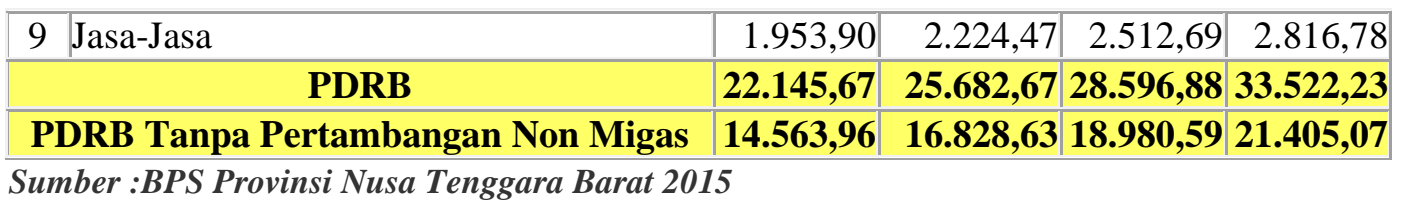

Berdasarkan uraian dari latar belakang di atas, maka penulis tertarik untuk mengangkat judul Analisis Ekonomi Potensial Sebagai Dasar Dalam Perencanaan dan Pertumbuhan Pembangunan Kota Bima Provinsi NTB. Dengan permasalahan utama penelitian, yaitu: Sektor dan subsektor ekonomi apa yang potensial di Kota Bima, berdasarkan kriteria keunggulan komparatif, keunggulan kompetitif, dan spesialisasi? Dan Bagaimana pola dan struktur pertumbuhan ekonomi di Kota Bima baik secara sektoral maupun secara agregat terhadap Provinsi Nusa Tenggara Barat?.

\section{KAJIAN PUSTAKA}

\section{A. Pembangunan Dan Pertumbuhan Ekonomi Daerah}

Pada awal pemikiran tentang pembangunan ekonomi sering ditemukan adanya pandangan yang mengidentikkan pembangunan dengan perkembangan (pertumbuhan). Seluruh pemikiran tersebut didasarkan pada aspek perubahan, dimana pembangunan dan pertumbuhan, secara keseluruhan mengandung unsur perubahan. Kedua hal tersebut memiliki perbedaan prinsipil, karena masingmasing memiliki latar belakang, hakikat dan prinsip kontinuitas yang berbeda, meskipun keduanya memiliki bentuk refleksi perubahan (Bratakusumah, 2003). Menurut Jhingan (1988), beberapa ahli ekonomi seperti Schumpeter dan Ursula Hicks, telah membuat perbedaan antara pertumbuhan ekonomi dan pembangunan ekonomi. Pertumbuhan menurut Schumpeter merupakan perubahan secara spontan dan terputus dalam keadaan stasioner yang senantiasa mengubah dan mengganti situasi keseimbangan yang ada sebelumnya. Sementara pembangunan ekonomi merupakan suatu proses perubahan yang dilakukan melalui upaya-upaya terencana untuk meningkatkan kesejahteraan masyarakat secara ekonomi dengan ditunjang oleh faktor-faktor non ekonomi lainnya (Mangiri, 2000). Namun seiring perkembangan dan era globalisasi seperti sekarang ini, konsep pembangunan dan pertumbuhan ekonomi berjalan seiring, dimana jika terjadi pembangunan, maka pertumbuhan merupakan sisi dampak dari adanya suatu pembangunan.

Selanjutnya, dalam konteks pembangunan ekonomi daerah maka pengertian daerah (region) itu sendiri berbeda-beda tergantung pada aspek tinjauannya. Dari aspek ekonomi oleh Arsyad (1999) daerah mempunyai tiga pengertian yaitu:

1. Suatu daerah dianggap sebagai ruang dimana kegiatan ekonomi terjadi dan di dalam berbagai pelosok ruang tersebut terdapat sifat-sifat yang sama. Kesamaan sifat-sifat tersebut antara lain dari segi pendapatan per kapita, sosial budaya, geografis dan sebagainya. Daerah dalam pengertian seperti ini disebut daerah homogen.

2. Suatu daerah dianggap sebagai suatu ekonomi ruang yang dikuasai oleh satu atau beberapa pusat kegiatan ekonomi. Daerah dalam pengertian ini disebut daerah modal. 


\section{"Jurnal PenKoMi : Kajian Pendidikan dan Ekonomi" STKIP Bima Vol. 2, No. 1 Januari 2019

3. Suatu daerah adalah suatu ekonomi ruang yang berada di bawah satu administrasi tertentu seperti satu Provinsi, kabupaten/kota, kecamatan, dan sebagainya. Jadi daerah di sini didasarkan pada pembagian administrasi suatu negara. Daerah dalam pengertian seperti ini dinamakan daerah administrasi.

Berdasarkan deskripsi di atas, maka pengertian ketiga lebih banyak digunakan dalam praktek pembangunan ekonomi daerah. Wilayah daerah biasanya lebih terbuka dibandingkan dengan wilayah nasional. Pergerakan sumber daya antar daerah lebih bebas bila dibandingkan dengan pergerakan sumber daya antar negara. Hal ini dimungkinkan karena halangan berupa tarif, kuota, lisensi ekspor dapat dikatakan tanpa hambatan antar daerah.

Seperti yang telah dikemukakan di atas bahwa pelaksanaan pembangunan ekonomi daerah bertujuan untuk meningkatkan dan memperluas peluang kerja bagi masyarakat. Dalam rangka mencapai tujuan tersebut, pemerintah daerah dan masyarakat harus bersama-sama mengambil inisiatif memanfaatkan seluruh potensi yang ada secara optimal dalam membangun daerah untuk kesejahteraan masyarakat. Sjafrizal (1997) mengatakan untuk mencapai tujuan pembangunan daerah, kebijaksanaan utama yang perlu dilakukan adalah mengusahakan semaksimal mungkin agar prioritas pembangunan daerah sesuai dengan potensi yang dimilikinya. Hal ini perlu diusahakan karena potensi pembangunan yang dihadapi oleh masing-masing daerah sangat bervariasi. Karena itu, bila prioritas pembangunan daerah kurang sesuai dengan potensi yang dimiliki oleh masingmasing daerah, maka sumber daya yang ada kurang dapat dimanfaatkan secara maksimal. Keadaan tersebut mengakibatkanrelatif lambatnya proses pertumbuhan ekonomi daerah bersangkutan. Hal ini menunjukkan bahwa pembangunan ekonomi dikatakan berjalan jika ditandai dengan adanya pertumbuhan ekonomi. Terkait dengan pertumbuhan ekonomi daerah, maka teori-teori pembangunan daerah banyak membahas penggunaan alat analisis dan metode statistik dalam menganalisis perekonomian suatu daerah serta teori tentang berbagai faktor yang mempengaruhi pertumbuhan ekonomi daerah. Todaro (2000) mengatakan bahwa ada tiga faktor atau komponen utama dalam pertumbuhan ekonomi. Pertama, akumulasi modal yang meliputi semua bentuk dan jenis investasi baru yang ditanamkan pada tanah, peralatan fisik dan sumber daya manusia. Kedua, pertumbuhan penduduk yang beberapa tahun selanjutnya dengan sendirinya membawa pertumbuhan angkatan kerja dan ketiga adalah kemajuan teknologi. Lebih lanjut Kuznets (1999) mendefinisikan pertumbuhan ekonomi sebagai kenaikan jangka panjang dalam kemampuan suatu negara untuk menyediakan semakin banyak jenis barang ekonomi bagi penduduknya. Kemampuan ini tumbuh sesuai dengan kemajuan teknologi, penyesuaian kelembagaan dan ideologi yang diperlukannya (Jhingan, 1999). Suatu perekonomian dikatakan mengalami pertumbuhan atau berkembang apabila tingkat kegiatan ekonomi lebih tinggi daripada yang telah dicapai pada masa sebelumnya. Artinya perkembangan baru tercipta apabila jumlah barang dan jasa yang dihasilkan (tingkat output) dalam perekonomian tersebut menjadi bertambah besar pada tahun-tahun berikutnya. Menurut Syafrizal (2002), teori pertumbuhan ekonomi daerah dapat dibagi atas empat kelompok besar, yang masing-masing didasarkan pada asumsi yang berbeda, sehingga memberikan kesimpulan yang berlainan pula. Kelompok

\section{0 | Program Studi Pendidikan Ekonomi, Sekolah Tinggi Keguruan dan Ilmu Pendidikan (STKIP)} Bima 


\section{"Jurnal PenKoMi : Kajian Pendidikan dan Ekonomi" STKIP Bima Vol. 2, No. 1 Januari 2019

pertama dinamakan sebagai export base modelsyang dipelopori oleh North pada tahun 1956. Dalam teori export base dijelaskan adanya perbedaan sumber daya dan keadaan geografis antara daerah, yang menyebabkan masing-masing daerah mempunyai keuntungan lokasi dalam beberapa sektor atau jenis kegiatan produksi. Keuntungan tersebut dapat dimanfaatkan menjadi kegiatan basis ekspor dan sebagai sektor potensial (sektor basis) bagi pertumbuhan ekonomi yang bersangkutan bila kegiatan tersebut dapat didorong pertumbuhannya. Untuk mengetahui keuntungan lokasi suatu wilayah, dapat dilakukan melalui studi terhadap sumber daya alam yang terdapat di wilayah yang bersangkutan, seperti tingkat kesuburan tanah, keadaan geografis, jaringan jalan dan kualitas sumber daya manusia. Selanjutnya untuk mengetahuisecara kualitatif dapat diketahui melalui teknik statistik antara lain dengan perhitungan Location Quotient. Kelompok kedua lebih banyak berorientasi pada kerangka pemikiran neo classic. Teori ini dipelopori oleh Stein pada tahun 1964, kemudian dikembangkan lebih lanjut oleh Roman pada tahun 1965 dan Siebert pada tahun 1969. Model neo classic mendasarkan analisisnya pada fungsi produksi. Sama halnya dengan analisis pada pertumbuhan ekonomi nasional, kelompok ini berpendapat bahwa unsur-unsur yang menentukan pertumbuhan ekonomi daerah adalah modal, sumber daya alam, sumber daya manusiadan lalu lintas terhadap pertumbuhan ekonomi regional. Kelompok ketiga menggunakan alur pemikiran ala Keynes dan menamakan pendekatannya sebagai cumulative causation models. Teori ini dipelopori oleh Myrdal pada tahun 1957 dan kemudian diformulasikan lebih lanjut oleh Kaldor pada tahun 1970. Penganut teori cumulative causation berpendapat bahwa peningkatan pemerataan pembangunan antar daerah tidak dapat hanya diserahkan pada kekuatan pasar sebagaimana yang dikemukakan oleh kaum neo classic. Bagaimanapun pemerintah perlu melakukan campur tangan secara aktif dalam bentuk program pembangunan wilayah, terutama untuk daerah yang tergolong masih terbelakang. Kelompok keempat lazim dinamakan sebagai core periphery models yang mula-mula diajukan oleh Friedman pada tahun 1966. Kelompok core periphery models menekankan analisisnya padahubungan yang erat dan saling mempengaruhi antar pembangunan kota (core) dan desa (periphery). Menurut teori ini gerak pembangunan perkotaan akan lebih banyak ditentukan oleh keadaan desa-desa di sekitarnya. Sebaliknya corak pembangunan daerah pedesaan juga sangat ditentukan oleh arah pembangunan daerah perkotaan. Dengan demikian aspek interaksi antar daerah sangat ditonjolkan.

\section{B. Struktur Ekonomi Dan Pergeseran Sektoral}

Secara teoritis, struktur ekonomi suatu wilayah dapat dilihat dari berbagai sisi. Dumairy (1996) membagi struktur ekonomi berdasarkan empat macam sudut tinjauan. Pertama, berdasarkan tinjauan makro sektoral, yang membagi perekonomian menjadi struktur agraris (agriculture), industri (industrial) atau niaga (commerce), tergantung pada sektoryang menjadi tulang punggung perekonomian suatu wilayah. Kedua, berdasarkan tinjauan keruangan (spasial), yang membagi perekonomian menjadi struktur pedesaan (tradisional) atau perkotaan (modern). Ketiga, berdasarkan tinjauan penyelenggaraan, yang menjadikan perekonomian berstruktur etatis, egaliter atau borjuis. Predikat ini

\section{1| Program Studi Pendidikan Ekonomi, Sekolah Tinggi Keguruan dan llmu Pendidikan (STKIP)} Bima 


\section{"Jurnal PenKoMi : Kajian Pendidikan dan Ekonomi" STKIP Bima Vol. 2, No. 1 Januari 2019

tergantung pada siapa atau kalangan mana yang menjadi pemeran utama dalam kegiatan perekonomian suatu wilayah. Keempat, struktur ekonomi dapat dilihat berdasarkan tinjauan birokrasi pengambilan keputusan, yaitu struktur ekonomi yang sentralistik atau desentralistik. Dalam kaitannya dengan struktur ekonomisuatu wilayah, Todaro (2000) mengatakan bahwa proses pertumbuhan ekonomi mempunyai kaitan erat dengan perubahan struktural dan sektoral. Beberapa perubahan komponen utama struktural ini mencakup pergeseran secaraperlahan-lahan aktifitas pertanian ke sektor nonpertanian dan dari sektor industri ke sektor jasa. Suatu wilayah yang sedang berkembang proses pertumbuhan ekonominya akan tercermin dari penggeseran sektor ekonominya. Yaitu tercermin dari pergeseran sektor ekonomi tradisional dimana sektor pertanian akan mengalami penurunan di satu sisi dan peningkatan peran sektor nonpertanian di sisi lainnya. Terkait dengan proses pembangunan daerah, maka struktur ekonomi memiliki peran penting dalam konsep pendekatan model pembangunan daerah. Sebagaimana yang dikemukakan Aziz (1994), pendekatan sektoral dalam perencanaan pembangunan daerah selalu dimulai dengan pertanyaan yang menyangkut sektor ekonomi apa yang perlu dikembangkan, kemudian dilanjutkan dengan pertanyaan di mana aktivitas sektor tersebut akan dijalankan dan kebijakan (strategi dan langkah-langkah) apa yang perlu diambil dalam mencapai tujuan pembangunan.

\section{Teori Basis Ekonomi Dan Sektor Ekonomi Potensial}

Salah satu teori ekonomi yang dikembangkan dalam rangka meningkatkan perekonomian daerah adalah teori basis ekspor (atau teori basis ekonomi). Menurut Arsyad (1999), teori ini menyatakan bahwa faktor penentu utama pertumbuhan ekonomi suatu daerah berhubungan langsung dengan permintaan barang dan jasa dari luar daerah. Pertumbuhan industri yang menggunakan sumber daya lokal, termasuk tenaga kerja dan bahan baku untuk diekspor akan menghasilkan kekayaan daerah dan menciptakan peluang kerja (job creation). Daerah mempunyai kesempatan untuk mengembangkan sumber daya yang dimiliki dengan memanfaatkan tenaga kerja yang ada termasuk dari luar daerah dalam upaya meningkatkan peluang ekspor. Lebih lanjut dalam analisisnya, teori basis ekonomi biasanya menggunakan data PDRB untuk mengidentifikasi dan menentukan sektor potensial. Apabila sektor potensial tersebut dikembangkan dengan baik akan mempunyai pengaruh yang signifikan terhadap pertumbuhan ekonomi daerah, yang pada akhirnya dapat meningkatkan pendapatan daerah secara optimal. Mengacu pada teori ekonomi basis tersebut maka Arsyad (2008) menjelaskan bahwa teknik Location Quotient (LQ) dapat membagi kegiatan ekonomi suatu daerah menjadi dua golongan yaitu:

1. kegiatan sektor ekonomi yang melayani pasar di daerah itu sendiri maupun di luar daerah yang bersangkutan. Sektor ekonomi seperti ini dinamakan sektor ekonomi potensial (basis);

2. kegiatan sektor ekonomi yang hanya dapat melayani pasar di daerah itu sendiri dinamakan sektor ekonomi tidak potensial (non basis) atau local industry.

Menurut Syafrizal (2002), dalam kerangkateori basis ekspor ini, diketahui bahwa peningkatan ekspor terjadi apabila suatu daerah memiliki keuntungan

\section{2 | Program Studi Pendidikan Ekonami, Sekolah Tinggi Keguruan dan Ilmu Pendidikan (STKIP)} Bima 


\section{"Jurnal PenKoMi : Kajian Pendidikan dan Ekonomi" STKIP Bima Vol. 2, No. 1 Januari 2019

kompetitif (competitive advantage) yang cukup besar pada beberapa sektor ekonomi. Dijelaskan pula bahwa dengan teori basis ekspor ini, bahwa untuk melihat besarnya keuntungan kompetitif perekonomian suatu daerah dapat dilakukan dengan penaksiran multiplierekspor dan analisis shift share.

\section{Keunggulan Komparatif Dan Keunggulan Kompetitif Wilayah}

Pada era otonomi daerah seperti sekarang ini, setiap daerah memiliki kebebasan dalam menentukan arah dan kebijakan pembangunan ekonomi wilayah. Untuk menentukan arah dan kebijakan pembangunan ekonomi di suatu daerah sangat diperlukan informasi mengenai potensi ekonomi wilayah. Potensi ekonomi wilayah dapat diketahui dengan mengidentifikasi keunggulan dan kelemahan berbagai sektor maupun subsektor ekonomi di wilayah tersebut. Sektor ekonomi yang memiliki keunggulan, memiliki prospek yang lebih baik untuk dikembangkan dan diharapkan dapat mendorong sektor-sektor ekonomi lain untuk berkembang. Keunggulan perekonomian wilayah tersebut secara garis besar terdiri atas keunggulan komparatif dan keunggulan kompetitif (daya saing). Istilah keunggulan komparatif (comparative advantage) mula-mula dikemukakan oleh Ricardo (1917) terkait dengan bahasan perdagangan antar dua wilayah. Ricardo membuktikan bahwa bila dua wilayah yang saling berdagang masing-masing mengkonsentrasikan diri untuk mengekspor barang yang memiliki keunggulan komparatif, maka kedua wilayah tersebut akan mendapatkan keuntungan. Ide tersebut bukan saja bermanfaat dalam perdagangan internasional tetapi juga sangat penting diperhatikan dalam ekonomi regional. Pengetahuan terhadap keunggulan komparatif suatu daerah dapat digunakan untuk mendorong perubahan struktur ekonomi daerah ke arah sector yang mengandung keunggulan komparatif. Jadi, apabila sektor yang memiliki keunggulan komparatif bagi suatu daerah telah teridentifikasi maka pembangunan sektor tersebut dapat disegerakan tanpa menunggu tekanan mekanisme pasar yang sering berjalan terlambat (Tarigan, 2003). Pada era perdagangan bebas seperti sekarang ini, keunggulan kompetitif mendapat perhatian lebih besar daripada keunggulan komparatif. Keunggulan kompetitif menunjukkan kemampuan daerah untuk memasarkan produknya ke luar daerah. Dalam analisis ekonomi regional, keunggulan kompetitif dimaknai sebagai kemampuan daya saing kegiatan ekonomi suatu daerah terhadap kegiatan ekonomi yang sama di daerah lainnya. Keunggulan kompetitif merupakan cermin dari keunggulan pertumbuhan ekonomi suatu wilayah terhadap wilayah lainnya yang dijadikan benchmarkdalam suatu kurun waktu. Dalam kaitannya dengan keunggulan kompetitif, maka keunggulan komparatif suatu kegiatan ekonomi dapat dijadikan suatu pertanda awal bahwa kegiatan ekonomi tersebut punya prospek untuk juga memiliki keunggulan kompetitif. Jika suatu sektor memiliki keunggulan komparatif karena besarnya potensi sektor tersebut maka kebijakan yang diprioritaskanbagi pengembangan kegiatan ekonomi tersebut dapat berimplikasi kepada terciptanya keunggulan kompetitif. Kegiatan ekonomi yang memiliki keunggulan komparatif sekaligus keunggulan kompetitif akan sangat menguntungkan perekonomian suatu wilayah. Terkait dengan keunggulan komparatif dan keunggulan kompetitif, maka berdasarkan kegiatan ekonominya suatu wilayah dapat saja memiliki kedua jenis

\section{3 | Program Studi Pendidikan Ekonami, Sekolah Tinggi Keguruan dan Ilmu Pendidikan (STKIP)} Bima 
keunggulan tersebut secara bersama-sama. Hal ini sangat dipengaruhi oleh satu atau gabungan beberapa factor berikut ini (Tarigan, 2003);

1. Memiliki potensi sumber daya alam.

2. Penguasaan masyarakat terhadap teknologi mutakhir dan keterampilanketerampilan khusus lainnya.

3. Aksesibilitas wilayah yang baik.

4. Memiliki marketyang baik atau dekat dengan market.

5. Wilayah yang memiliki sentra-sentra produksi tertentu atau terdapatnya aglomerasi dari berbagai kegiatan ekonomi.

6. Ketersediaan buruh (tenaga kerja) yang cukup dan memiliki keterampilan baik dengan upah yang relatif rendah.

7. Mentalitas masyarakat yang baik untuk pembangunan: jujur, terbuka, bekerja keras, dapat diajak bekerja sama dan disiplin.

8. Kebijaksanaan pemerintah yang mendukung pada terciptanya keunggulan suatu kegiatan ekonomi wilayah.

\section{E. Spesialisasi Perekonomian}

Perekonomian suatu wilayah dikatakan terspesialisasi jika suatu wilayah memprioritaskan pengembangan suatu sektor ekonomi melalui kebijakan yang mendukung kemajuan sektor tersebut (Muzamil, 2001). Pengembangan sektor prioritas tersebut dapat dilakukan melalui investasi dan peningkatan sumber daya manusia pada sektor tersebut. Spesialisasi dalam perekonomian merupakan hal penting dalam rangka memacu pertumbuhan ekonomi suatu wilayah. Dikatakan, jika suatu wilayah memiliki spesialisasi pada sektor tertentu maka wilayah tersebut akan memiliki keunggulan kompetitif dari spesialisasi sektor tersebut (Soepono, 1993).

Beberapa ahli ekonomi mulai memperhitungkan efek spesialisasi terhadap perekonomian suatu wilayah. Menurut Kuncoro (2002), salah satu upaya yang dapat ditempuh untuk meningkatkan keterkaitan antar wilayah adalah melalui proses pertukaran komoditas antar daerah. Hal ini dapat ditempuh melalui penciptaan spesialisasi antar daerah.

Berbagai macam alat analisis telah dikembangkan untuk melihat tingkat spesialisasi regional. Marquillas dalam Soepono (1993) memodifikasi analisis shift shareklasik dengan memasukkan efek alokasi untuk melihat spesialisasi suatu sektor dalam suatu wilayah. Selanjutnya Kim dalam Kuncoro (2002) mengembangkan indeks krugman untuk melihat spesialisasi regional di Amerika Serikat.

\section{F. Pola Dan Struktur Pertumbuhan Ekonomi Daerah}

Gambaran pola dan struktur pertumbuhan ekonomi daerah merupakan analisis yang cukup penting untuk melihatkondisi perekonomian suatu daerah. Dengan melihat pola dan struktur pertumbuhan ekonomi dapat tergambar potensi relatif perekonomian suatu daerah baik secara agregat maupun sektoral terhadap daerah lain di sekitarnya. Untuk melihat pola dan struktur pertumbuhan ekonomi daerah, para ahli ekonomi biasanya menggunakan analisis Klassen Typology.

\section{4 | Program Studi Pendidikan Ekonomi, Sekolah Tinggi Keguruan dan Ilmu Pendidikan (STKIP) Bima}


"Jurnal PenKoMi : Kajian Pendidikan dan

Ekonomi" STKIP Bima Vol. 2, No. 1 Januari 2019

Syafrizal (1997) mengemukakan bahwa analisis ini digunakan untuk membagi serta membedakan suatu daerah menjadi empat klasifikasi yaitu:

1. Daerah maju dan tumbuh cepat (rapid growth region) apabila kabupaten/kota memiliki laju pertumbuhan ekonomi dan tingkat pendapatan per kapita lebih tinggi dibandingkan dengan pertumbuhan ekonomi dan pendapatan per kapita Provinsi;

2. Daerah maju tapi tertekan (retarded region) apabila laju pertumbuhan ekonomi kabupaten/kota lebih kecil dari pada laju pertumbuhan ekonomi Provinsi akan tetapi pendapatan per kapita kabupaten/kota lebih besar dari pendapatan per kapita Provinsi;

3. Daerah berkembang cepat (growing region) yaitu daerah yang berkembang dengan cepat apabila laju pertumbuhan ekonomi kabupaten/kota lebih besar dibandingkan dengan laju pertumbuhan ekonomi Provinsi akan tetapi pendapatan per kapita kabupaten/kota lebih rendah dari pendapatan per kapita Provinsi;

4. Daerah relatif tertinggal (relatively backward region) apabila kabupaten/kota memiliki tingkat pertumbuhan ekonomi dan pendapatan per kapita lebih rendah dari tingkat pertumbuhan ekonomi dan pendapatan perkapita Provinsi.

Untuk melihat pola dan struktur pertumbuhan ekonomi sektoral dapat dilakukan melalui pendekatan analisis tipologi Klassen seperti yang dilakukan oleh Apriliyanto (2003), dengan membedakan suatu sektor ekonomi menjadi empat klasifikasi yaitu;

1. Sektor potensial dan tumbuh cepat apabila suatu sektor memiliki laju pertumbuhan dan kontribusi lebih tinggi dibandingkan dengan pertumbuhan dan kontribusi sektor yang sama pada tingkat Provinsi;

2. Sektor maju tapi tertekan apabila laju pertumbuhan suatu sektor lebih kecil dari pada laju pertumbuhan sektor yang sama pada tingkat Provinsi akan tetapi kontribusinya di wilayah tersebut lebih besar dari kontribusi sektor yang sama pada tingkat Provinsi;

3. Sektor berkembang cepat yaitu sektor yang berkembang dengan cepat apabila laju pertumbuhan sektor kabupaten/kota lebih besar dibandingkan dengan laju pertumbuhan sektor pada tingkat Provinsi akan tetapi strukturnya pada tingkat kabupaten/kota lebih rendah dari struktur sektor yang sama pada tingkat Provinsi;

4. Sektor relatif tertinggal apabila kabupaten/kota memiliki sektor yang tingkat pertumbuhan dan kontribusinya lebih rendah dari tingkat pertumbuhan dan kontribusi sektor yang sama pada tingkat Provinsi.

\section{METODE PENELITIAN}

Metode analisis yang dipakai dalam penelitian ini adalah metode analisis Location Quatient (LQ). Analisis Location Quotient digunakan untuk menunjukkan besar kecilnya peranan sektor perekonomian suatu region dengan membandingkan sektor yang sama pada wilayah yang lebih besar. Metode ini digunakan untuk mengidentifikasi sektor ekonomi potensial yang menjadi unggulan yang dapat dikembangkan pada suatu wilayah dan dipergunakan untuk

\section{5 | Program Studi Pendidikan Ekonami, Sekolah Tinggi Keguruan dan llmu Pendidikan (STKIP) Bima}




\section{"Jurnal PenKoMi : Kajian Pendidikan dan Ekonomi" STKIP Bima Vol. 2, No. 1 Januari 2019}

mengidentifikasi keunggulan komparatif (comparative advantage) suatu wilayah (Thoha dan Soekarni, 2000).

Penelitian ini menggunakan metode yang mengacu pada formulasi yang dikemukakan oleh Arsyad (1999).

$$
L Q=\frac{\mathrm{Yi}, \mathrm{k} / \mathrm{Yi}, \mathrm{p}}{\mathrm{Yk} / \mathrm{Yp}}
$$

Keterangan;

Yi,k : Nilai tambah PDRB sektor i di Kota Bima

Yk : Total PDRB di Kota Bima

Yi,p : Nilai tambah PDRB sektor i di Provinsi Nusa Tenggara Barat

Yp : Total PDRB di Provinsi Nusa Tenggara Barat

Dari hasil analisis Location Quotient (LQ) maka didapat kesimpulan:

1. Jika nilai $L Q>1$, berarti sektor tersebut merupakan sektor potensial, yang menunjukkan suatu sektor yang mampu melayani pasar baik di dalam maupun di luar Kota Bima;

2. Jika nilai LQ $<1$, berarti sektor tersebut bukan merupakan sektor potensial, yang menunjukkan suatu sektor yang belum mampu melayani pasar di Kota Bima;

3. Jika nilai $\mathrm{LQ}=1$, berarti suatu sektor hanya mampu melayani pasar di Kota Bima saja atau belum dapat memasarkan hasil sektor tersebut ke luar daerah lain.

Berikut data hasil analisis LQ dengan menggunakan data PDRB Kota Bima pada tahun 2010 sampai tahun 2013, ditampilkan pada tabelberikut ini :

Tabel 3 : Hasil Analisis Location Quotient (LQ)

\begin{tabular}{|c|c|c|c|c|c|c|c|c|}
\hline \multirow{2}{*}{ No } & \multirow{2}{*}{ Lapangan Usaha } & \multicolumn{5}{|c|}{ Analisa LQ } & & \multirow{2}{*}{ Kategori } \\
\hline & & 2012 & 2013 & 2014 & 2015 & Rata-Rata & & \\
\hline 1 & Pertanian & 0.912 & 0.058 & 0.841 & 0.843 & 0.663 & - & non basis \\
\hline 2 & $\begin{array}{l}\text { Pertambangan dan } \\
\text { Penggalian }\end{array}$ & 0.004 & 0.000 & 0.005 & 0.005 & 0.004 & - & non basis \\
\hline 3 & Industri Pengolahan & 0.812 & 0.002 & 0.767 & 0.718 & 0.574 & - & non basis \\
\hline 4 & $\begin{array}{l}\text { Listrik, Gas dan Air } \\
\text { Bersih }\end{array}$ & 2.912 & 0.000 & 2.526 & 2.370 & 1.952 & + & Basis \\
\hline 5 & Bangunan & 1.051 & 0.004 & 1.021 & 0.996 & 0.768 & - & non basis \\
\hline 6 & $\begin{array}{l}\text { Perdagangan, Hotel dan } \\
\text { Restoran }\end{array}$ & 1.349 & 0.024 & 1.297 & 1.271 & 0.985 & - & non basis \\
\hline 7 & $\begin{array}{l}\text { Pengangkutan dan } \\
\text { Komunikasi }\end{array}$ & 2.320 & 0.012 & 2.265 & 2.246 & 1.711 & + & Basis \\
\hline 8 & $\begin{array}{l}\text { Keuangan, Persewaan } \\
\text { dan Jasa Perusahaan }\end{array}$ & 1.150 & 0.002 & 1.102 & 1.072 & 0.832 & - & non basis \\
\hline 9 & Jasa-Jasa & 2.726 & 0.027 & 2.605 & 2.643 & 2.000 & + & Basis \\
\hline
\end{tabular}

Berdasarkan tabel hasil analisa data dengan metode Location Quotient (LQ) maka, pada tahun 2012 sampai dengan tahun 2015, dari sembilan sektor yang menjadi sektor ekonomi potensial yang dimiliki Kota Bima adalah pada 86 | Program Studi Pendidikan Ekonomi, Sekolah Tinggi Keguruan dan IImu Pendidikan (STKIP) Bima 


\section{"Jurnal PenKoMi : Kajian Pendidikan dan Ekonomi" STKIP Bima Vol. 2, No. 1 Januari 2019}

sektorJasa-jasa dengan persentase konstribusi adalah $21 \%$ dengan rata-rata tahun 2010 sampai 2013 adalah 2,00. setelah itu disusul dengan sektorlistrik, gas dan air bersih dengan persentase $21 \%$ dengan rata-rata 1,952 dan sektor pengangkutan dan komunikasi sebesar $18 \%$ dengan rata-rata 1,711. Sedangkan pada sektor pertanian, sektor pertambangan/penggalian, sektor industri pengolahan, sektor bangunan, sektor perdagangan, hotel dan restoran dan sektorkeuangan, persewaan dan jasa perusahaan tidak memberikan konstribusi untuk menempati sektor unggulan di Kota Bima.

Tahun 2012 sektor pertanian menjadi sektor yang mendekati sektor unggulan daerah hasil analisis LQ diperoleh 0,912 mendekati sektor unggulan, namun produk pertanian daerah Kota Bima pada tahun ini hanya mampu melayani pasar di Kota Bima saja atau belum dapat memasarkan hasil sektor tersebut ke luar daerah, keadaan ini sama halnya dengan sektor industri dan pengolahan. Sedangkan pada sektor pertambangan dan penggalian bukan merupakan sektor potensial, yang menunjukkan suatu sektor belum mampu melayani pasar di Kota Bima, hal ini disebabkan daerah Kota Bima belum memiliki asset pada sektor ini.Berbeda dengan perolehan rata-rata tahun 2012 sampai dengan tahun 2015, sektor Bangunan, sektor Perdagangan, hotel dan restoran, dan sektor keuangan mampu menjadi sektor potensial daerah kota bima pada tahun 2012. Hasilnya terlihat pada grafik berikut ini :

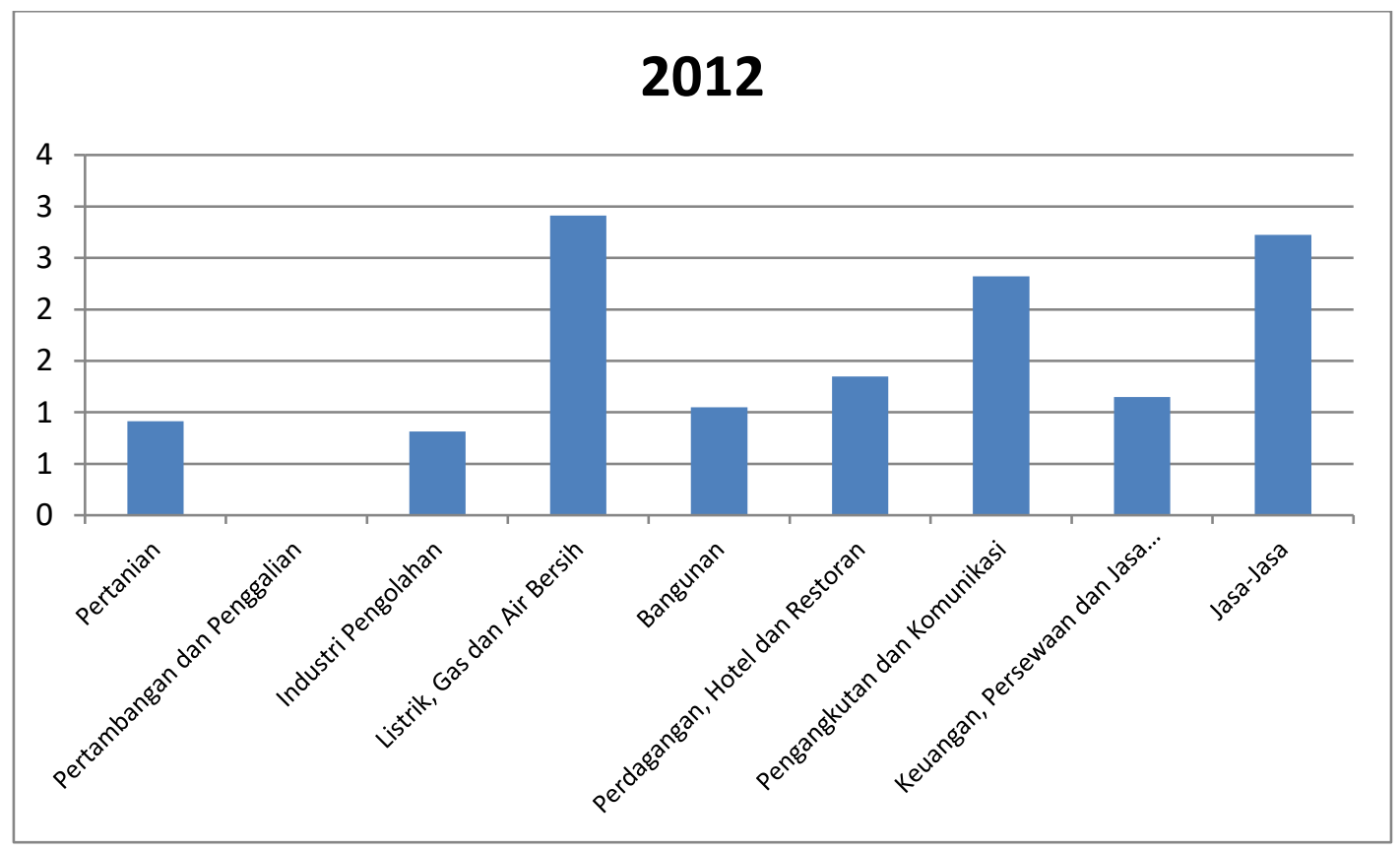

Sedangkan pada tahun 2013 Kota Bima mengalami penurunan pada semua sektor, sehingga menyebabkan semua sektor tidak menunjukkan adanya konstribusi signifikan terhadap sektor unggulan dalam perekonomian Kota Bima, kondisi melemahnya perekonomian tahun 2013 ini mempunyai relasi yang kuat dengan perubahan iklim ekonomi nasional dan adanya perubahan iklim dunia (global warning) sehingga memberi perubahan drastis pada sektor pertanian yang berimbas pada terpuruknya sektor lainnya. Pada aspek lain pengaruh kuat sistem

87 | Program Studi Pendidikan Ekonomi, Sekolah Tinggi Keguruan dan IImu Pendidikan (STKIP) Bima 


\section{"Jurnal PenKoMi : Kajian Pendidikan dan Ekonomi" STKIP Bima Vol. 2, No. 1 Januari 2019}

perpolitikan daerah dan iklim politik nasional tidak sehat menjadi salah faktor yang tidak bisa dihindari sehingga keadaan ekonomi nasional pada tahun 2013 menurun secara keseluruhan termasuk didaerah Kota Bima. Untuk lebih jelas terlihat pada grafik berikut :

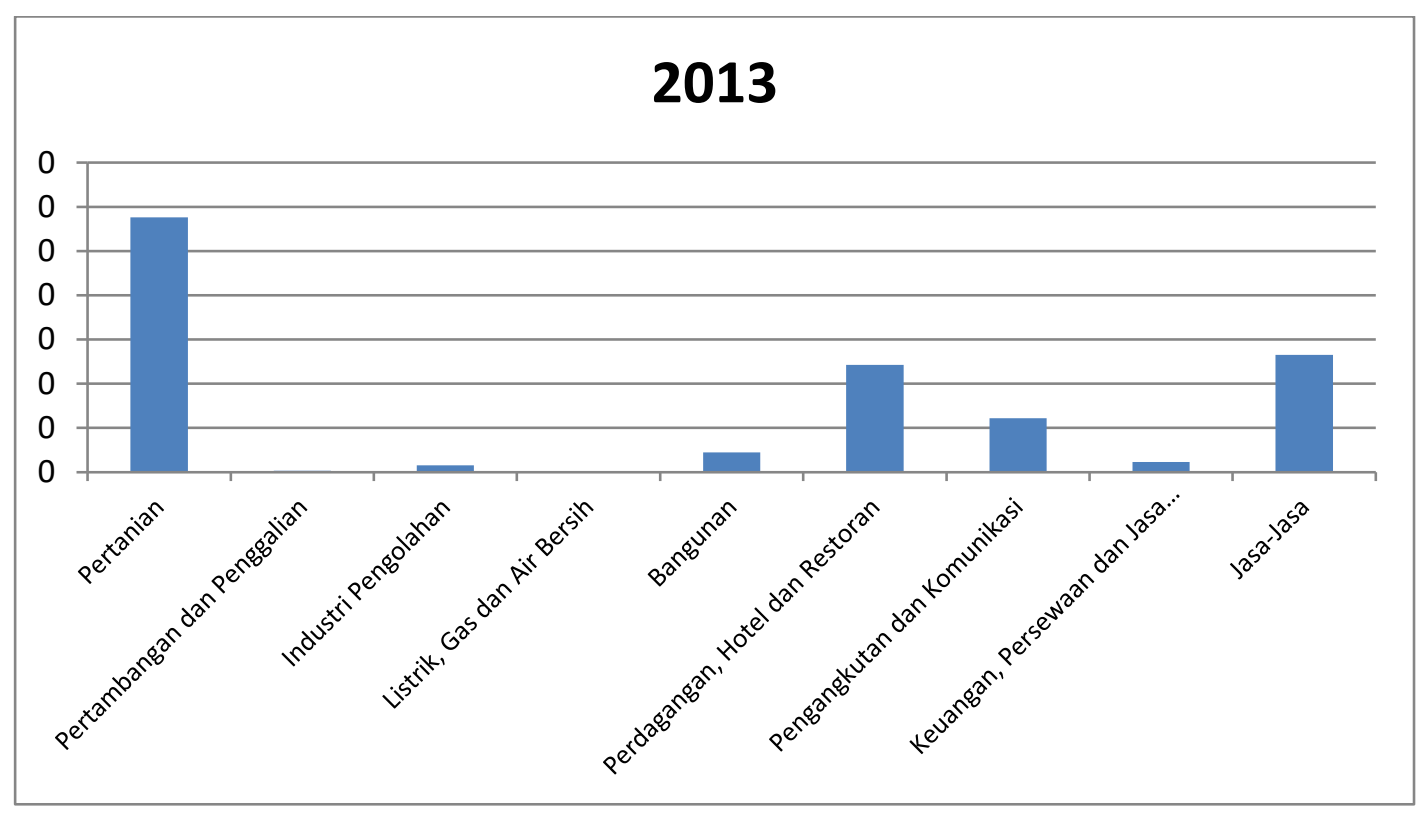

Tahun 2014 sektor pertanian dan sektor industri pengolahan hampir mendekati angka 1 yaitu masing-masing 0,841 dan 0,767 kedua sektor tersebut hanya mampu melayani pasar di Kota Bima saja atau belum dapat memasarkan hasil sektor tersebut ke luar daerah lain. Sedangkan sektor pertambangan dan penggalian hampir tidak ada perubahan yaitu sebesar 0,005. Sektor jasa-jasa mendominasi dengan angka tertinggi sebesar 2,643 disusul oleh sektor listrik, gas dan air bersih sebesar 2,370, sektor pengangkutan dan komunikasi sebesar 2,265. Ketiga sektor tersebut menjadi sektor andalan Kota Bima. Sementara itu sektor perdagangan, hotel dan restoran, sektor keuangan, persewaan, dan sektor bangunan masih merupakan sektor basis Kota Bima artinya ketiga sektor tersebut merupakan sektor potensial, yang menunjukkan suatu sektor yang mampu melayani pasar baik di dalam maupun di luar Kota Bima. Hal ini terlihat pada grafik berikut : 


\section{"Jurnal PenKoMi : Kajian Pendidikan dan Ekonomi" STKIP Bima Vol. 2, No. 1 Januari 2019}

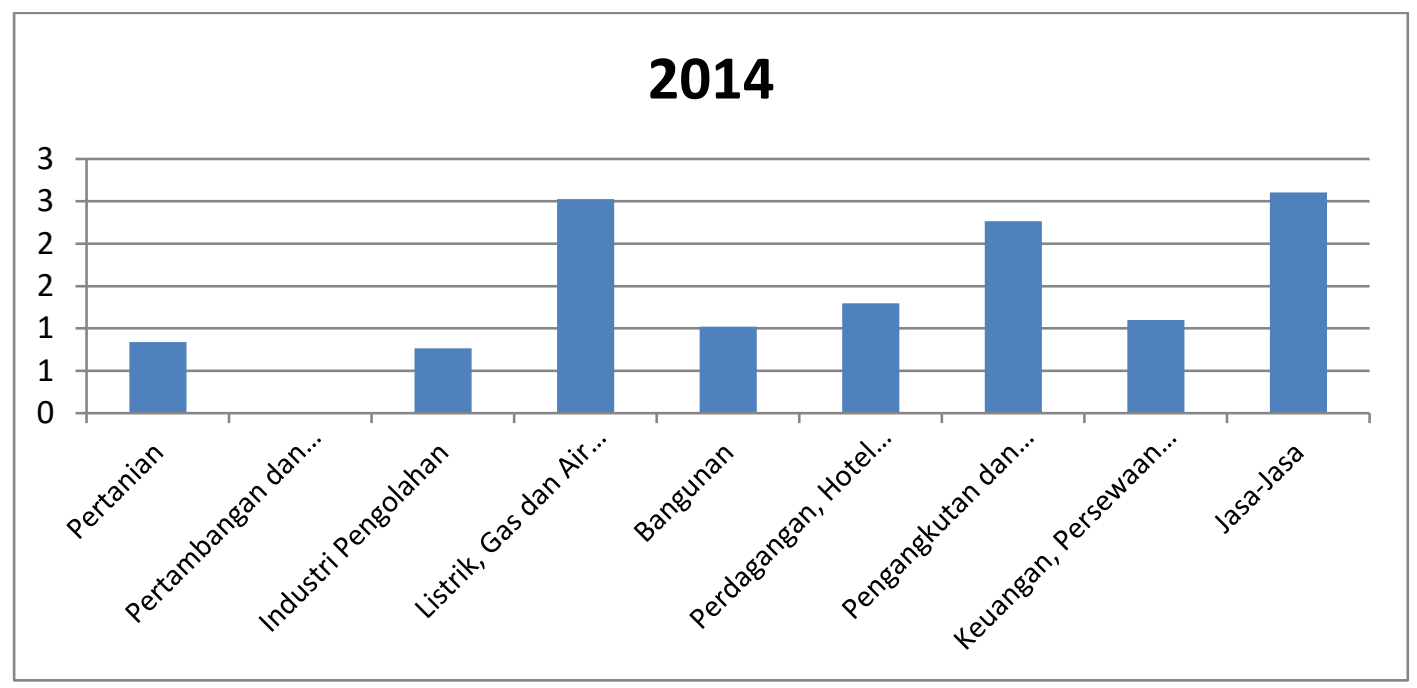

Tahun 2015, sektor jasa-jasa masih mendominasi dengan peringkat tertinggi sebesar 2,643 mengalami peningkatan dari tahun sebelumnya sebesar 0,038 disusul oleh sektor listrik, gas dan air bersih sebesar 2,370 kemudian sektor pengangkutan dan komunikasi sebesar 2,246. Ketiga sektor tersebut hamper setiap tahun mendominasi sektor-sektor yang lain kecuali tahun 2013 disebabkan karena di Kota Bima banyak perusahaan penyedia jasa-jasa atau perusahaan-perusahaan yang bergerak di bidang jasa-jasa khususnya jasa pengangkutan orang dan barang disebabkan oleh budaya orang Kota Bima yang suka keluar daerah dalam rangka studi/kuliah, berdagang dan mengambil barang di luar Kota Bima. Faktor lain adalah kondisi iklim dan geografis Kota Bima yang beriklim panas dan terik sehingga kebutuhan akan listrik, gas dan air bersih sangat tinggi. Sedangkan sektor perdagangan, hotel dan restoran dan sektor keuangan, persewaan dan jasa perusahaan tetap menjadi sektor basis dengan angka sebesar 1,271 dan 1,072 atau kedua sektor tersebut merupakan sektor potensial, yang menunjukkan suatu sektor yang mampu melayani pasar baik di dalam maupun di luar Kota Bima. Sementara itu sektor bangunan turun dari tahun 2006 dan tidak menjadi sektor basis lagi yaitu sebesar 0,996 artinya sektor tersebut bukan merupakan sektor potensial, yang menunjukkan suatu sektor yang belum mampu melayani pasar di Kota Bima. Keadaan tahun 2015 di Kota Bima terlihat pada grafik berikut ini : 


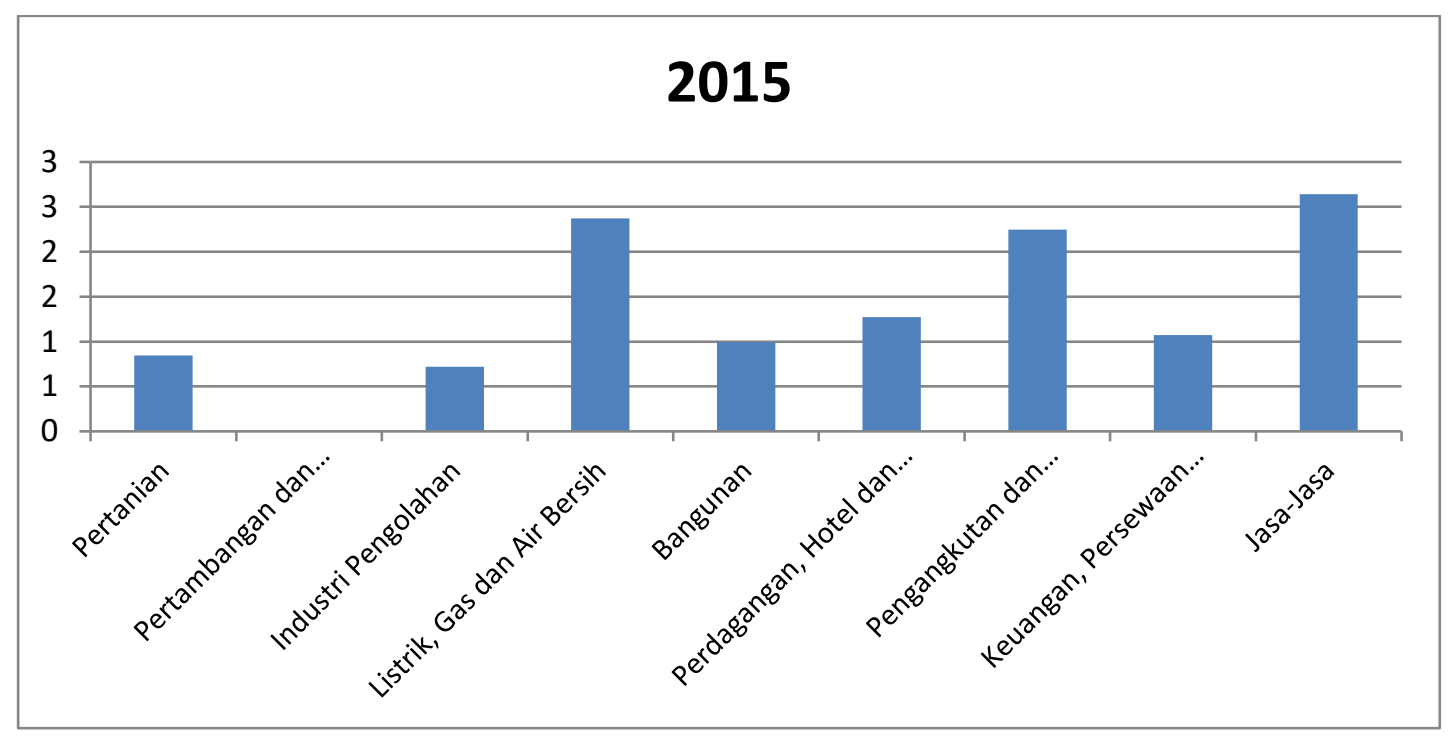

Sedangkan untuk rata-rata mulai tahun 2012-2015 dari hasil analisis LQ terlihat pada grafik berikut ini :

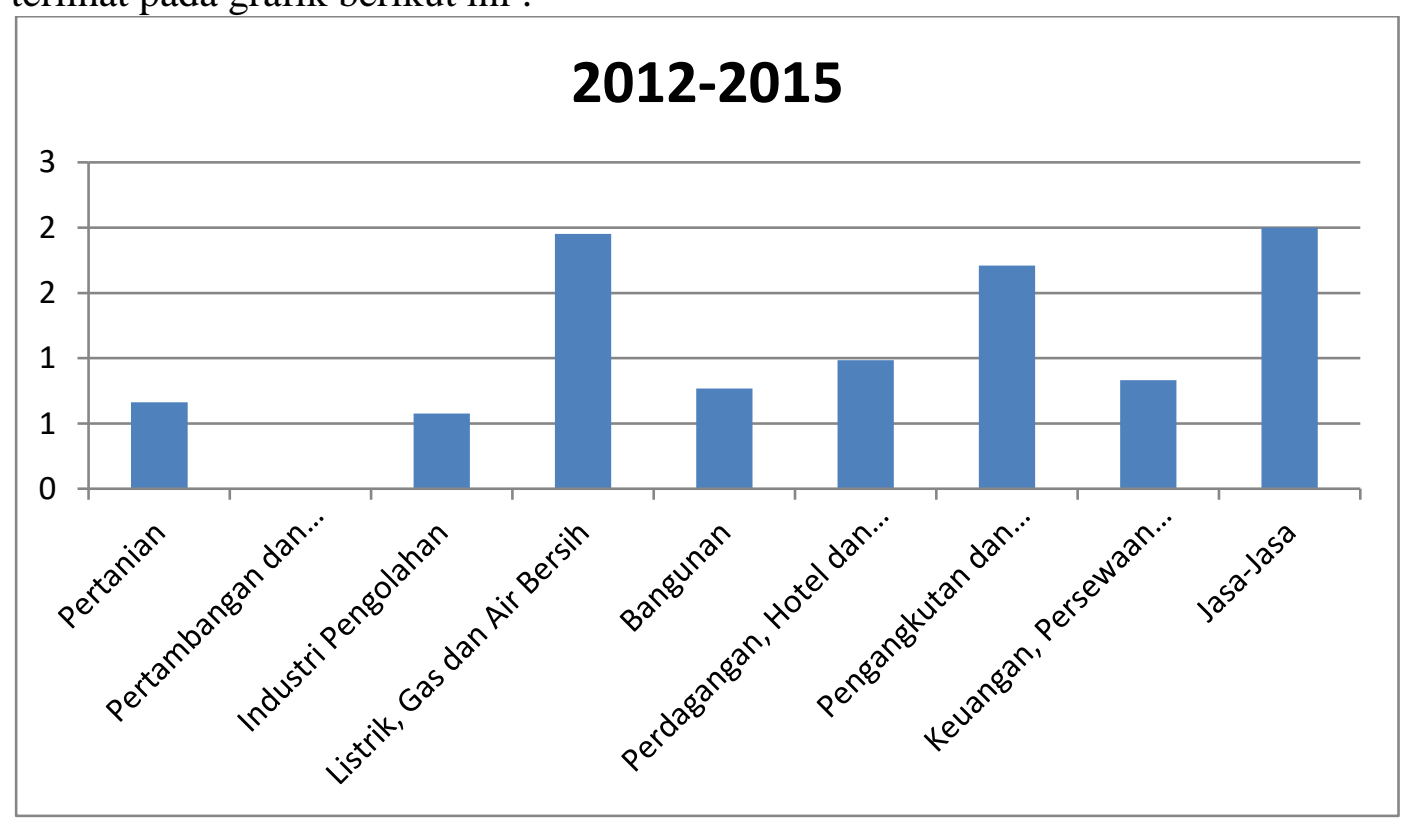

\section{KESIMPULAN}

Dari hasil analisis data dengan menggunakan analisis Location Quotient (LQ) di atasmaka dapat ditarik kesimpulan sebagai berikut :

a) Sektor jasa-jasa menempati peringkat tertinggi dengan rata-rata sebesar 2,000 dan masih menjadi sektor basis atau sektor tersebut merupakan sektor potensial, yang menunjukkan suatu sektor yang mampu melayani pasar baik di dalam maupun di luar Kota Bima disebabkan karena di Kota Bima banyak perusahaan yang bergerak di bidang jasa-jasa dan pelayanan.

b) Sektor listrik, gas dan air bersih serta sektor pengangkutan dan komunikasi masing-masing rata-rata sebesar 1,952 dan 1,711 tetap menjadi sektor basis 
artinya kedua sektor tersebut merupakan sektor potensial, yang menunjukkan suatu sektor yang mampu melayani pasar baik di dalam maupun di luar Kota Bima. Hal ini disebabkan karena kondisi iklim dan geografis Kota Bima yang beriklim tropis (panas dan terik) sehingga kebutuhan akan sektor listrik, gas dan air bersih sangat tinggi. Penyebab yang lain adalah budaya masyarakat Kota Bima yang suka ke luar daerah baik dalam rangka studi/kuliah, berdagang dan gemar mengambil barang secara langsung di luar Kota Bima.

c) Sementara itu sektor-sektor yg lain masing-masing dengan rata-rata yaitu : sektor perdagangan $(0,985)$, sektor keuangan, persewaan dan jasa perusahaan $(0,832)$, sektor bangunan $(0,768)$, sektor pertanian $(0,663)$, sektor industri pengolahan $(0,574)$ serta sektor pertambangan dan penggalian $(0,004)$ bukan merupakan sektor basis artinya sektor-sektor tersebut bukan merupakan sektor potensial, yang menunjukkan suatu sektor yang belum mampu melayani pasar di Kota Bima. Untuk lebih jelasnya tentang keadaan ekonomi potensial (basis) Kota Bima mulai tahun 2012 sampai dengan tahun 2015 terlihat dalam diagram analisis LQ berikut ini :

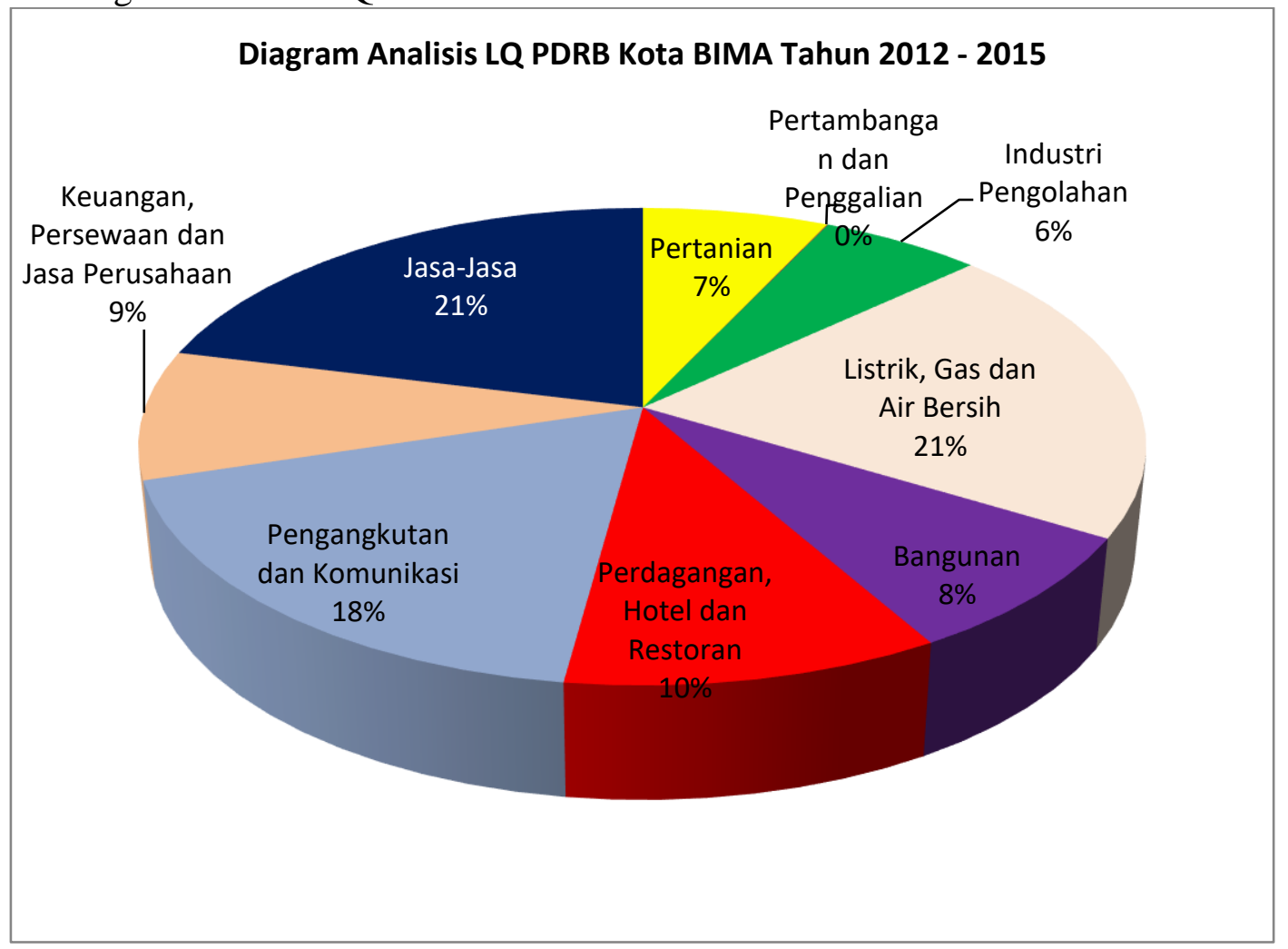

\section{DAFTAR PUSTAKA}

Adisasmita, Rahardo. 2008. Pengembangan Wilayah Konsep dan Teori, Graha Ilmu, Jakarta

Arsyad, Lincolyn. 1999. Pengantar Perencanaan dan Pembangunan Ekonomi Daerah, BPFE, Yogyakarta

Aziz, Iwan Jaya. 1994. Ilmu Ekonomi Regional dan Beberapa Aplikasinya Di Indonesia, Lembaga Penerbit FE-UI, Jakarta

91 | Program Studi Pendidikan Ekonomi, Sekolah Tinggi Keguruan dan Ilmu Pendidikan (STKIP) Bima 
"Jurnal PenKoMi : Kajian Pendidikan dan

Ekonomi" STKIP Bima Vol. 2, No. 1 Januari 2019

e-ISSN: 2614-6002

Badan Pusat Statistik. 2003. Pedoman Penghitungan PDRB Kabupaten/Kota: Pengertian Dasar (Buku 1).BPS, Jakarta

Badan Pusat Statistik Provinsi NTB. 2008. Produk Domestik Regional Bruto Provinsi NTB Tahun 2007(Draft Publikasi). BPS, NTB

Badan Pusat Statistik Kabupaten OKU Timur. 2008. Produk Domestik Regional Bruto Kota Bima 2007. BPS, Kota Bima

2007. Kota Bima dalam Angka Tahun 2007 (Draft

Publikasi). BPS, Kota Bima

Bratakusumah, Deddy dan Riyadi. 2003. Perencanaan Pembangunan Daerah. Gramedia Press, Jakarta

Budiharsono, Sugeng. 1995. Perencanaan Pembangunan Daerah. PAU-EK-UI, Jakarta

Dumairy. 1996. Perekonomian Indonesia. Erlangga, Jakarta

Jaya, Wihana Kirana. 1993. Pengantar Ekonomi Industri: Pendekatan Struktur, Perilaku dan Kinerja Pasar. BPFE, Yogyakarta

Jhingan, ML. 2000. Ekonomi Pembangunan dan Perencanaan. Rajawali Press, Jakarta

Kuncoro, Mudrajad dan Hairul Aswandi. 2002. Evaluasi Penetapan Kawasan Andalan: Studi Empiris DiKalimantan Selatan 1993-1999, Jurnal Ekonomi dan Bisnis Indonesia,Vol 17, Nomor 1, Tahun 2002 : 27-45, BPFE, Yogyakarta

Mangiri, Komet. 2000. Perencanaan Terpadu Pembangunan Ekonomi Daerah, Edisi Kedua, BPS, Jakarta

Marwah, Taufik dan Syirod Saleh. 2002. Potensi Relatif Sektor-Sektor Ekonomi Propinsi Sumatera Selatan. Kajian Ekonomi, Vol 1, Nomor 1, Tahun 2002: 1-13, Universitas Sriwijaya, Palembang

Muzamil. 2001. Analisis Pertumbuhan Ekonomi Kabupaten Musi Rawas. Tesis (Unpublished), Universitas Sriwijaya, Palembang

Nugraha, Yudhistira Arya. 2003. Analisis Sektor Ekonomi Potensial Kota Prabumulih, Tesis (Unpublished).Universitas Sriwijaya, Palembang

Republik Indonesia .1999. Ketetapan Majelis Permusyawaratan Rakyat No. IV/MPR/1999 Tentang Garis-Garis Besar Haluan Negara Tahun 19992004. Pustaka Setia, Bandung

Saimima, Habiba. 2003. Analisis Sektor Ekonomi Potensial Dalam Perencanaan Pembangunan Di Kota Ambon (Perbandingan Dengan Kabupaten Lain Di Propinsi Maluku), Tesis (Unpublished).Universitas Gajah Mada, Yogyakarta

Sinar Grafika. 2001. Propenas 2000-2004, UU No.25 Th.2000 Tentang Program Pembangunan Nasional Tahun 2000-2004. Sinar Grafika, Jakarta.

Sjafrizal. 2008. Ekonomi Regional Teori dan Aplikasi. Baduose Media, Padang Tarigan, Robinson. 2003. Ekonomi Regional. Bumi Aksara, Jakarta

Tarwiyanto, Junaidi. 1998. Analisis Faktor-Faktor Yang Mempengaruhi Pertumbuhan Ekonomi Sumatera Selatan, Tesis (Unpublished). Universitas Syiah Kuala, Banda Aceh

Todaro, M.P. 2000. Economic Development. Seventh Edition, New York University, Longman, London and New York

92 | Program Studi Pendidikan Ekonomi, Sekolah Tinggi Keguruan dan IImu Pendidikan (STKIP) Bima 
"Jurnal PenKoMi : Kajian Pendidikan dan

Ekonomi" STKIP Bima Vol. 2, No. 1 Januari 2019

e-ISSN: 2614-6002

Yusuf, Maulana. 1999. Model Rasio Pertumbuhan (MRP) sebagai Salah Satu Alat Analisis Alternatif dalam Perencanaan Wilayah dan Kota, Aplikasi Model: Wilayah Bangka-Belitung. Jurnal Ekonomi dan Keuangan Indonesia, Vol XLVII, Nomor 2, Tahun 1999 : 219-233 